\title{
External Auditory Canal Cholesteatoma: An Unusual Complication of Tympanoplasty
}

\author{
Borligegowda Viswanatha* and Maliyappanahalli Siddappa Vijayashree \\ Department of Otorhinolaryngology, Bangalore Medical College \&Research Institute, India
}

Submission: June 23, 2018; Published: July 13, 2018

*Corresponding author: BorligegowdaViswanatha, Department of Otorhinolaryngology, Bangalore Medical College \& Research Institute, India, Tel: 91-9845942832; Email: drbviswanatha@yahoo.co.in

\begin{abstract}
Cholesteatoma of the external auditory canal is very uncommon. Most cases occur spontaneously or after surgery (tympanoplasty, middle ear surgery, or mastoid surgery) and/or trauma in the auditory canal. Previous tympanoplasty is one of several known predisposing factors for external auditory canal cholesteatoma. In this article, the author reports 36 cases of external auditory canal cholesteatoma that occurred following a tympanoplasty. The mass was excised, and it was diagnosed on histopathology.
\end{abstract}

Keywords: External auditory canal;Cholesteatoma;Tympanoplasty

\section{Introduction}

Schofield introduced the term external auditory canal cholesteatomain 1893 in describing a cholesteatoma that had been caused by an insect [1].In 1854; Toynbee was the first author to describe that cholesteatoma originates from external auditory canal as epidermal sheets. Till 1980, cholesteatoma external auditory canal and keratosis obturans were considered as different presentation of the same disease [2]. Piepergerdes described cholesteatoma of the external auditory canal and keratosis obturans as two different pathological processes; keratosis obturans as keratin accumulation in the external auditory canal; and external auditory canal cholesteatoma as bone erosion resulting from squamous tissue on a specific spot of the external auditory canal [3]. In this article, the author reports 36 cases of external auditory canal cholesteatoma that occurred following a tympanoplasty. The mass was excised, and it was diagnosed on histopathology.

\section{Materials and Methods}

This prospective research study was done during the period 2002 to 2017.During this period there were 36 cases of external auditory canal cholesteatoma that occurred following tympanoplasty surgery, were treated at teaching hospital. 25 patients had undergone tympanoplasty and 11 patients had undergone cortical mastoidectomy with tympanoplasty.

\section{Symptoms and Signs}

Presenting symptoms were otorrhea in all 36 patients; chronic dull pain was the presenting symptom in 27 patients, 3 patients had hearing loss.25 patients had undergone tympanoplasty and 11 patients had undergone cortical mastoidectomy with tympanoplasty.

\section{Treatment}

All the patients underwent examination under microscope. In all the patients, mass was excised and external auditory canal cholesteatoma was diagnosed on histopathology(Figures 1 \& 2). In 30 patients, lesion was small and mastoid air cells were not involved (Figure 3). For these patients canaloplasty was done. 5 patients had a small posterior wall defect without involving the middle ear cavity. For these patients, canal-wall up mastoidectomy and canal wall reconstruction was done. One patient had a large posterior wall defect with involvement of the middle ear cavity and in this case, canal-wall down mastoidectomy was done. Postoperative period was uneventful. All the patients were followed up for one year and there was no recurrence.

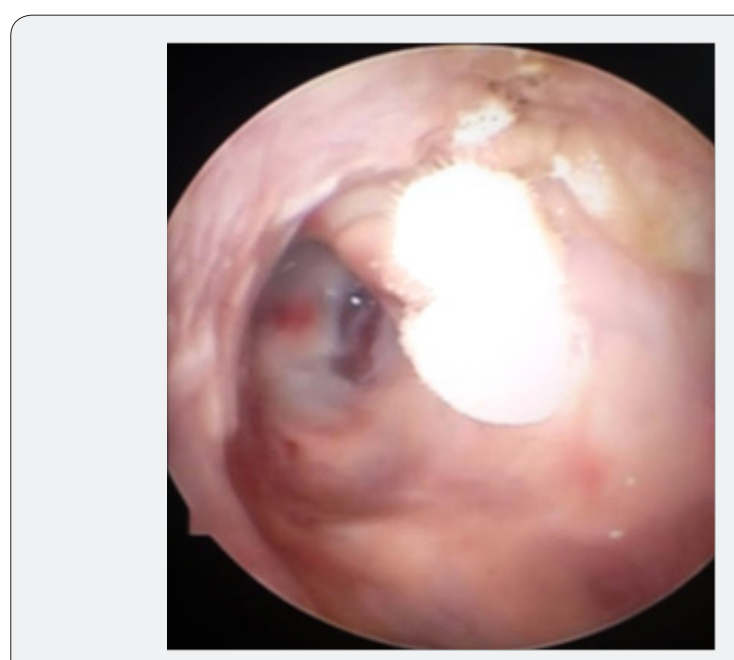

Figure 1: Showing whitish mass in the posterior canal wall. 


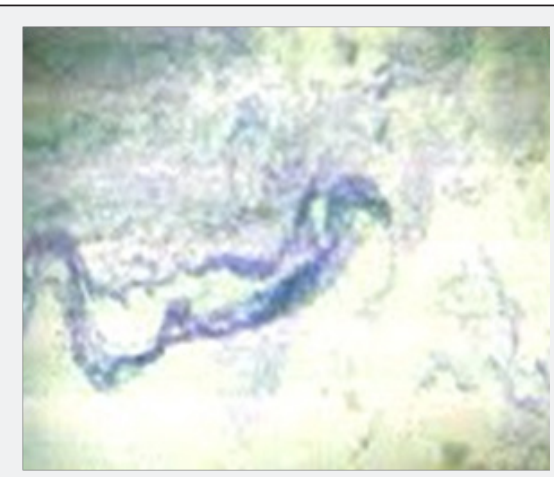

Figure 2: Photomicrograph of the cholesteatoma showing squamous epithelium and overlying lamellar sheets of keratin and inflammatory infiltrate.

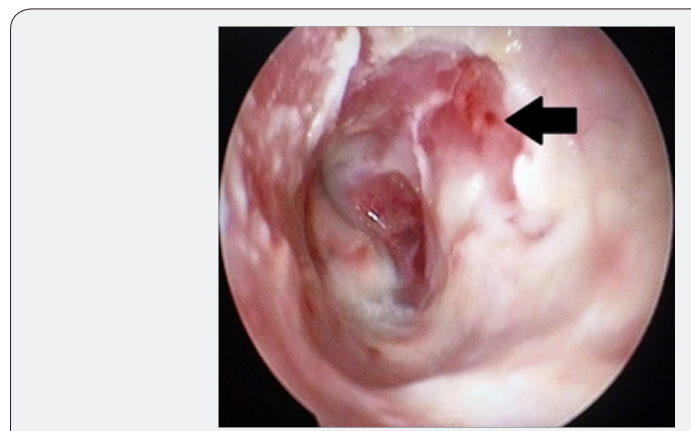

Figure 3: Showing posterior canal wall erosion [arrow].

\section{Discussion}

The exact etiology of external auditory canal cholesteatoma is unclear [4,5].Cholesteatoma of the external auditory canal is very uncommon, as it is seen in only 0.1 to $0.5 \%$ of patients who present with an otologic disorder $[2,5,6]$.The cholesteatoma of the external auditory canal may arise through several mechanisms. Occlusion or narrowing of the external auditory canal is the basic cause [7].Most cases occur spontaneously or after surgery (tympanoplasty, middle ear surgery, or mastoid surgery) and/or trauma in the auditory canal; preexisting ear canal stenosis or obstruction has also been described as a causative factor [8,9]. Brookes and Graham opined that when there is obstruction of the canal, desquamation of the epithelium continues, and the collection of impacted squamous debris may ultimately modify the canal lining and lead to cholesteatoma formation [10].Several classifications based on the Pathophysiological mechanism and the etiologies have been reported [5].Farrior [11] classified cholesteatoma of the external auditory canal into four groups:

a) Complicating congenital aural artesia and stenosis of the external auditory canal;

b) Following tympanoplasty, middle ear surgery or trauma to the skin of the external auditory canal;

c) Related to keratosis obturans; d) Associated with focal osteitis, sequestrisation of bone and inflammation of the skin of theexternal auditory canal.

In 1992, Holt [9] speculated upon the causes of cholesteatoma of the external auditory canal and listed five groups in which this entity may be seen:
a) Postoperative patients.
b) Post-traumatic patients.
c) Patients with ear canal stenosis (often congenital).
d) Patients with ear canal obstruction due to tumor or osteoma.

e) A large group of patients in which cause is unknown.

Affected patients typically present with otorrhea and a chronic, dull pain secondary to the local invasion of squamous tissue into the bony external auditory canal. Hearing loss is not common unless the cholesteatoma invades the middle ear or attic. Rarely cholesteatoma debris form in the ear canal to cause conductive hearing loss [3,7].The diagnosis is based on the history, clinical examination, and audiometric findings. Although external auditory canal cholesteatoma has characteristic imaging features (its defining feature on computed tomography is a softtissue attenuating mass in the canal with erosion of the adjacent bone), imaging is usually not performed for diagnosis[4,7].It is required when there is extension beyond external auditory canal [12].CT scan is important to evaluate for disease extension into the middle ear cavity and for the integrity of the facial nerve canal, tegmen tympani, and mastoid air cells, because these features may change the surgical management of external auditory canal cholesteatoma [4].

The reported complications of an external auditory canal cholesteatoma include facial palsy, ossicle erosion, and labyrinthine fistula[11] These complications can occur as a result of an extensive cholesteatoma extending to the mastoid or the middle ear [9] Extensive invasion in to the mastoid cavity has a propensity to involve the vertical segment of the facial nerve $[2,7,12,13]$. Those external auditory canal cholesteatomas that occur as a complication of surgery or trauma are more likely than other forms to violate the middle ear cavity, and they commonly require surgical treatment [13]. The choice of procedure is determined by the extent of the cholesteatoma. Canaloplasty is sufficient for small lesions that do not involve the mastoid air cell. For patients with a small posterior wall defect that does not involve the middle ear cavity, canal-wall up mastoidectomy and canal wall reconstruction should be done. For patients who have a large posterior wall defect and involvement of the middle ear cavity, canal-wall down mastoidectomy is recommended $[5,13]$.

\section{References}

1. Schotield RE (1893) Cholesteatoma of auditory canal caused by a bug. Lancet 142(3659): 929. 
2. Zanini FD, Ameno ES, Magaldi So, Lámar RA (2005) Cholesteatoma of the external auditory canal: A case report. Braz J Otorhinotaryngol 71(1): 91-93.

3. Piepergerdes MC, Kramer BM, Behnke EE (1980) Keratosis obturans and external auditory canal cholesteatoma. Laryngoscope 90(3): 383391.

4. Viswanatha B (2009) External auditory canal cholesteatoma: A rare complication of tympanoplasty. Ear nose \& throat journal 88(11): 1206-1217.

5. Lee DH, Jun BC, Park CS, Cho KI (2005) A case of osteoma with cholesteatoma in the external auditory canal. Auris Nasus Larynx 32(3): 281-284.

6. Orita Y, Nishizaki K, Fukushima K (1998) Osteoma with cholesteatoma in the external auditory canal. In J Pediatr Otorhinolaryngol 43(3): 289-293.

7. Cheng Y, Shiao A, Lein CA (2005) Pediatric external canal cholesteatoma with extensive invasion into the mastoid cavity. Int J Pediatr Otolaryngol 69(4): 561-566.

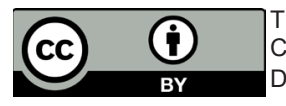

This work is licensed under Creative Commons Attribution 4.0 License

DOI: $10.19080 /$ GJO.2018.16.555942
8. Heilbrun MH, Salzman KL, Glastonbury CM (2003) External auditory canal cholesteatoma: Clinical and imaging spectrum. AINR Am J Neuroradiol 24(4): 751-756.

9. Holt JJ (1992) Ear canal cholesteatoma. Laryngoscope 102(6): 608613.

10. Brookes GB, Grahams MD (1984) Posttraumatic cholesteatoma of the external auditory canal. Laryngoscope 94(5-1): 667-670.

11. Farrior J (1990) Cholesteatoma of the external ear. Am J Otol 11: 113116.

12. Viswanatha B (2007) A case of osteoma with cholesteatoma of the external auditory canal and cerebellar abscess. Int J Pediatr Otorhinolaryngol Extra 2(1): 34-39.

13. Martin DW, Selesnic SH, Parrisier SC (1999) External auditory canal cholesteatoma with erosion into the mastoid. Otolaryngol Head Neck Surgery 121(3): 298-300.

\section{Your next submission with Juniper Publishers will reach you the below assets}

- Quality Editorial service

- Swift Peer Review

- Reprints availability

- E-prints Service

- Manuscript Podcast for convenient understanding

- Global attainment for your research

- Manuscript accessibility in different formats

( Pdf, E-pub, Full Text, Audio)

- Unceasing customer service

Track the below URL for one-step submission https://juniperpublishers.com/online-submission.php 